\title{
Analisis Tingkat Kepercayaan Publik Terhadap STIKI Ditinjau Asal Mahasiswa Berbasis SIG
}

\author{
I Kadek Adiana Putra \\ Masuk: 10022019 / Diterima: 08052019 / Dipublikasi: 30062019 \\ (c) 2019 Fakultas Hukum dan IImu Sosial UNDIKSHA dan IGI
}

\begin{abstract}
The use of GIS technology on tabulation, analysis, overlaying and presenting data to the maps, statistics and graphs, so that can easily find out the distribution patterns of students. The purpose of this study was to determine the level of public confidence on STMIK STIKOM Indonesia through the pattern distribution of new students on 2015/2016 until 2017/2018. In this study using descriptive analytical methods by confirming student statistical data into GIS formats and databases. Distribution pattern of new students shows that origin of agglomerated students in several regions, especially Bali, Java, NTT, and NTB, among the dominant regions, Bali Province have contributes until $60 \%$ of the total number of students. The high level of public trust is influenced by increase in the number of students cannot be separated from the high contribution of alumni as a medium of information and promotion. An increase of public confidence institutions on STMIK STIKOM Indonesia, tendency the distribution pattern of the student's the influenced election of the workforce and ease of accessibility
\end{abstract}

Key words: GIS; Public Trust; Distribution Pattern; Student's Origin

\begin{abstract}
Abstrak Teknlogi SIG digunakan dalam tabulasi, analisis, overlay dan menyajikan data dalam bentuk peta, statistic dan grafik, sehingga dapat dengan mudah mengetahui pola distribusi dan jumlah mahasiswa pada masing-masing angkatan. Tujuan dari penelitian ini adalah untuk mengetahui tingkat kepercayaan public terhadap STMIK STIKOM Indonesia melalui pola distribusi mahasiswa baru pada angkatan 2015/2016 sampai 2017/2018. Dalam penelitian ini mengeggunakan metode deskriptif analitik dengan mengkonfersi data statistic mahasiswa kedalam format dan basis data SIG.

Pola distribusi mahasiswa baru menunjukan bahwa asal mahasiswa teraglomerasi pada beberapa wilayah yaitu Bali, Jawa, NTT, dan NTB, diantara wilayah yang dominan, Provinsi Bali memberikan kontribusi $60 \%$ dari total jumlah mahasiswa. Tingginya kepercayaan masyarakat dipengaruhi besarnya derajat konsistensi dan peningkatan jumlah mahasiswa tidak lepas kontribusi alumnus yang cukup tinggi sebagai media informasi dan promosi. Adanya peningkatan kepercayaan masyarakat terhadap lembaga perguruan tinggi STMIK STIKOM Indonesia, dan Kecendrungan pola distribusi asal mahasiswa mengarah pada pemilihan dunia kerja dan kemudahan dalam aksesbilitas
\end{abstract}

Kata kunci : SIG; Kepercayaan Publik; Pola Distribusi; Asal Mahasiswa

\section{Pendahuluan}

Tingginya tingkat distribusi asal mahasiswa menjadi indikator meningkatnya kepercayaan masyarakat untuk mendapatkan pendidikan lanjut diperguruan guruan tinggi. Selain tingkat kepuasan masyarakat, distribusi asal mahasiswa secara tidak langsung sebagai media promosi untuk calon mahasiswa baru dalam menentukan pilihan belajar ke depan.

I Kadek Adiana Putra

STIKOM Indonesia

putraadiana@ymail.com
Teknik visualiasi data dalam bentuk pemetaan dalam SIG dapat menjadi salah satu cara efektif untuk meyakinkan pengambil kebijakan di berbagai level administratif untuk menentukan prioritas masalah, (Rahmanti dan Prasetyo, 2012). Pemanfaatan teknologi Sitem Informasi Geografis (SIG) dalam hal ini diupayakan untuk menganalisis dan memetakan jumlah dan distribusi mahasiswa STMIK STIKOM Indonesia angkatan tahun 2015/2016 sampai 2017/2018. 


Berdasarkan uraian tersebut
dirumuskan permasalahan
penelitian yaitu bagaimana pola distribusi
daerah asal mahasiswa STMIK STIKOM
Indonesia angkatan tahun 2015/2016 -
$2017 / 2018$ ? Dengan diketahuinya pola
distribusi mahasiswa maka dapat
diketahui tingkat kepercayaan publik
terhadap STMIK STIKOM Indonesia
khususnya yang ada di Bali bahkan yang
berada di luar Bali.

Pendekatan

keruangan

merupakan suatu cara pandang atau kerangka analisis yang menekankan eksistensi ruang sebagai penekanan. Eksistensi ruang dalam perspektif geografi dapat dipandang dari struktur (spatial structure), pola (spatial pattern), dan proses (spatial processes) (Rohsulina dan Husyain, 2015).

Pola (pattern) merupakan kekhasan distribusi gejala tertentu di dalam ruang atau wilayah. Pola keruangan ditunjukkan dengan mengamati gejala berdasarkan kenampakan point features, line features, dan areal features. Pola keruangan titik adalah kekhasan distribusi titik-titik (mencerminkan gejala geografi tertentu) dalam ruang yang diamati, Yunus dalam (Rohsulina dan Husyain, 2015).

Sistem Informasi Geografis yang berbasiskan komputer digital antara lain ditandai dengan dikembangkan sistem basis data sebagai salah satu basis dari suatu bentuk sistem informasi. Pola sistem informasi secara umum memanipulasi dunia-nyata (real-world) sedemikian rupa sehingga diabstaraksikan menjadi sekelompok data dasar; data ini diolah dengan menggunakan fungsifungsi; kemudian disampaikan ke para pengguna (users) sebagai informasi yang sesuai dengan yang diinginkan, (Yani, 2016).

SIG terdiri atas empat subsistem, yaitu: data masukkan (input), data storage and retrieval, data manipulation and analysis, dan data keluaran (reporting) (Prahasta dalam Ramadhan dan Suprayogi, 2016). Secara terperindi empat subsistem dalam SIG yaitu: (1) data masukan (Input): berfungsi untuk mengumpulkan dan menyiapkan data spasial dan data atribut serta mengkonversi ataumentransformasi format data aslinya ke dalam format data SIG, (2) data keluaran (Reporting): berfungsi untuk menampilkan atau menyajikan keluaran seluruh basis data baik dalam bentuk softcopy maupun hardcopy, seperti: grafik, tabel, peta, dan lainlain, (3) data Storage and Retrieval: berfungsi mengorganisasikan data spasial dan data atribut dalam basis data sehinngga mudah dipanggil, di update, dan di edit, dan (4) data Analysis and Manipulation: berfungsi untuk menentukan informasi-informasi yang dapat dihasilkan oleh SIG serta melakukan manipulasi dan pemodelan data untul menghasilkan informasi yang diharapkan.

Pada dasarnya sistem ini merupakan suatu manajemen database yang memungkinkan analisis informasi dari berbagai sumber data yang berbeda, dengan catatan data tersebut memiliki unsur-unsur kespasialan, sperti koordinat lokasi geografis, tercakup dalam kelompok area geografis tertentu, dan lain - lain. Teknologi ini juga memungkinkan analisis hubungan spasial antara dimensi yang berbeda (Rahmanti dan Prasetyo, 2012).

Warella dalam Kompas (2016) menyatakan, beberapa indikator objektif suatu perguruan tinggi dikatakan berkelas dunia, antara lain berapa banyak guru besar yang dimiliki dan karya-karya ilmiah spektakuler yang masuk dalam jurnal internasional bereputasi tinggi, banyak guru besar yang mengajar di luar negeri dan sebaliknya banyak guru besar luar negeri yang mengajar di suatu perguruan tinggi, berarti perguruan tinggi itu dikenal dan dipercaya secara luas. Selain itu semakin banyak karya yang diterbitkan 
dalam jurnal internasional dan sudah dipatenkan, tentu menjadikan perguruan tinggi tersebut diakui oleh kalangan internasional.

\section{Metode}

Penelitian ini merupakan penelitian deskriptif yang bertujuan untuk menganalisis pola distribusi asal mahasiswa STMIK STIKOM Indonesia dari angkatan 2015/2016-2017/2018 berbasis SIG serta menganalisis dominasi asal. Rancangan dalam penelitian ini seperti terlihat pada Gambar 1.

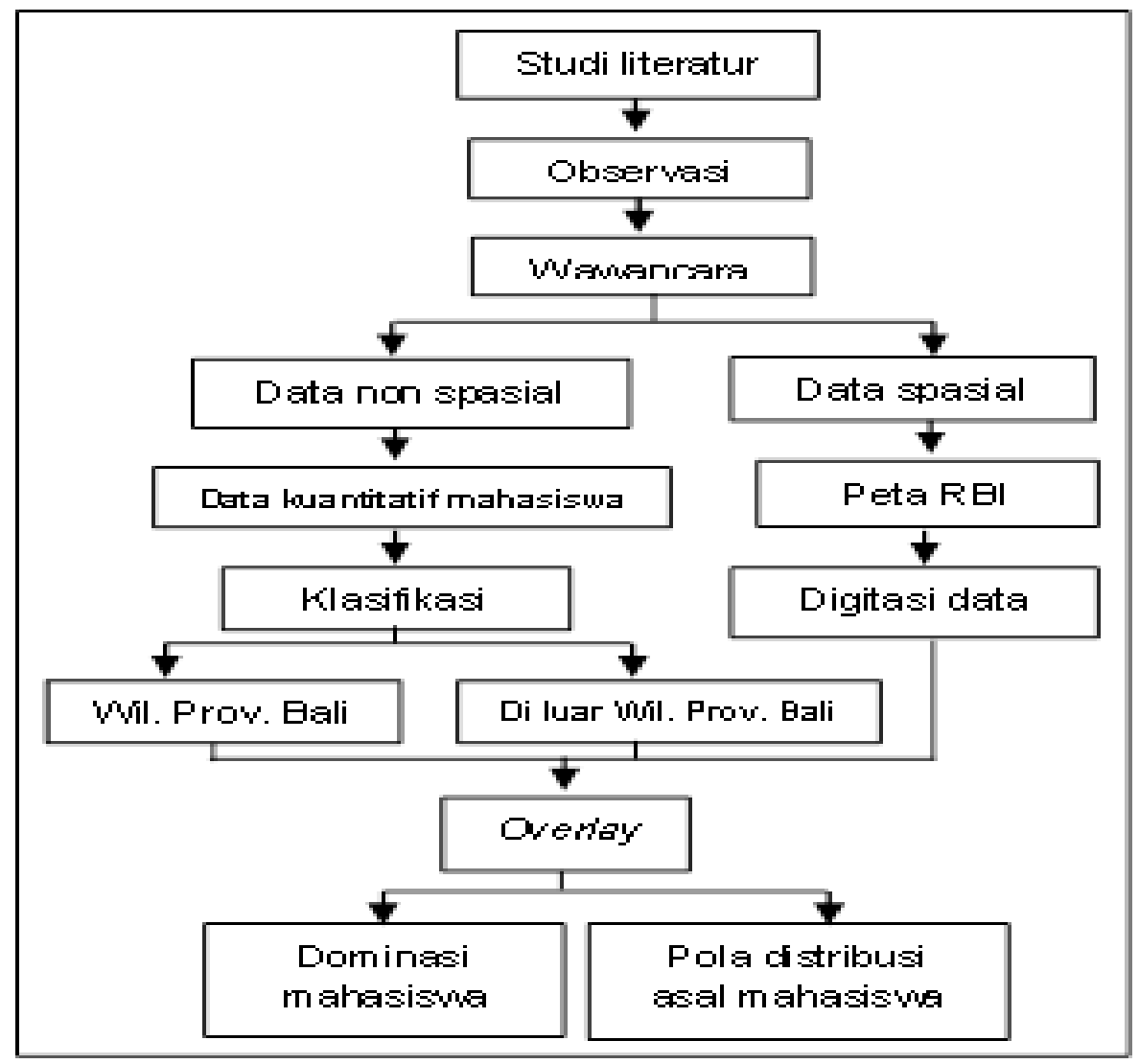

Gambar 1. Rancangan Penelitian

Teknik analisis data yang dilakukan dalam penelitian ini adalah teknik analisis data sekunder dan teknik analisis SIG. Teknik analisis data sekunder dengan mentabulasi ke dalam bentuk tabel dan grafik maupun peta, kemudian diuraikan dalam bentuk deskripsi.

\section{Hasil dan Pembahasan \\ 3.1 Pola distribusi mahasiswa STIMIK STIKOM Indonesia}

Dalam penelitian ini penyajian data secara spasial menggunakan peta untuk menunjukan distribusi dan perbandingan jumlah mahasiswa. Data penerimaan dan Grafik perbandingan mahasiswa STIMIK STIKOM Indonesia dari angkatan 2015/2016 - 2017/2018 dirinci berdasarkan provinsi dapat dilihat pada Tabel 1 dan Gambar 1. 
Tabel 1. Data Penerimaan Mahasiswa STIMIK STIKOM Indonesia Dari Angkatan 2015/2016 - 2017/2018 Dirinci Berdasarkan Provinsi.

\begin{tabular}{|l|c|c|c|}
\hline \multicolumn{1}{|c|}{ Provinsi } & $\mathbf{2 0 1 5 / 2 0 1 6}$ & $\mathbf{2 0 1 6 / 2 0 1 7}$ & $\mathbf{2 0 1 7 / 2 0 1 8}$ \\
\hline \hline Bali & 672 & 731 & 665 \\
\hline DIY & 1 & & 1 \\
\hline Jawa Barat & 1 & 4 & 6 \\
\hline Jakarta & 6 & 1 & 3 \\
\hline Jawa Tengah & & & 3 \\
\hline Jawa Timur & 28 & 31 & 31 \\
\hline Kalimantan Barat & & & 1 \\
\hline Kalimantan Tengah & & 1 & 1 \\
\hline Kalimantan Timur & 2 & & \\
\hline Kalimantan Selatan & 93 & 146 & 156 \\
\hline NTB & 43 & 95 & 252 \\
\hline NTT & 3 & 1 & 2 \\
\hline Papua & 1 & & \\
\hline Papua Barat & 1 & & 1 \\
\hline Sulawesi Selatan & & 1 & \\
\hline Sulawesi Barat & & 2 & \\
\hline Sulawesi Tengah & & & 1 \\
\hline Sumatera Selatan & 1 & & 665 \\
\hline Sumatera Utara & 3 & 2 & $\mathbf{1 1 2 9}$ \\
\hline Lampung & 53 & & 1015 \\
\hline Timor Leste & $\mathbf{8 5 5}$ & $\mathbf{1 0 1 5}$ & \\
\hline Kosong TOTAL & & & \\
\hline \multicolumn{1}{|c|}{} & & & \\
\hline
\end{tabular}

Sumber: Data pokok Kemahasiswaan STIMIK, 2018

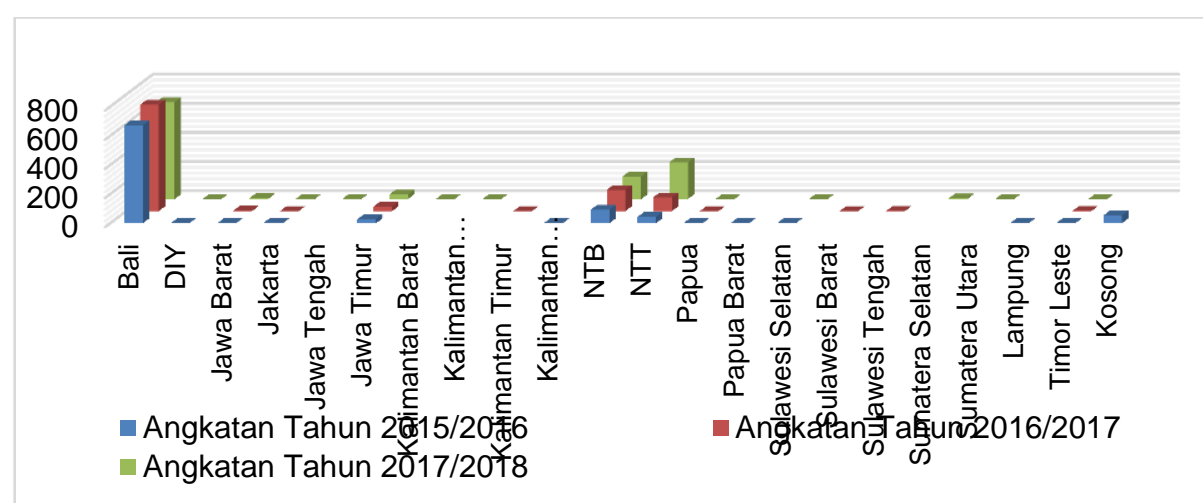

Gambar 2. Perbandingan Mahasiswa dari Angkatan 2015/2016 - 2017/2018.

Dari data penerimaan mahasiswa baru menunjukan terjadi peningkatan jumlah mahasiswa dari 855 manjadi 1129 pada tahun 2018. Jika dilihat dari jumlah mahasiswa masuk Provinsi Bali sebagai tuan rumah berada pada peringkat yang paling tinggi dari masing-masing tahun yaitu 672 atau $78.60 \%$ pada angkatan 2015/2016, kemudian pada angkatan 2016/2017 sebesar 731atau $71.95 \%$ dan pada angkatan 2017/2018 sejumlah 665 atau $58.90 \%$. Untuk lebih jelas distribusi mahasiswa baru secara spasial dapat dilihat pada Gambar 3.

Secara umum jumlah mahasiswa di luar Provinsi Bali tidak sebesar jumlah mahasiswa yang berasal dari Bali sendiri yang mencapi lebih dari $50 \%$ dari total semua mahasiswa STMIK STIKOM Indonesia. 


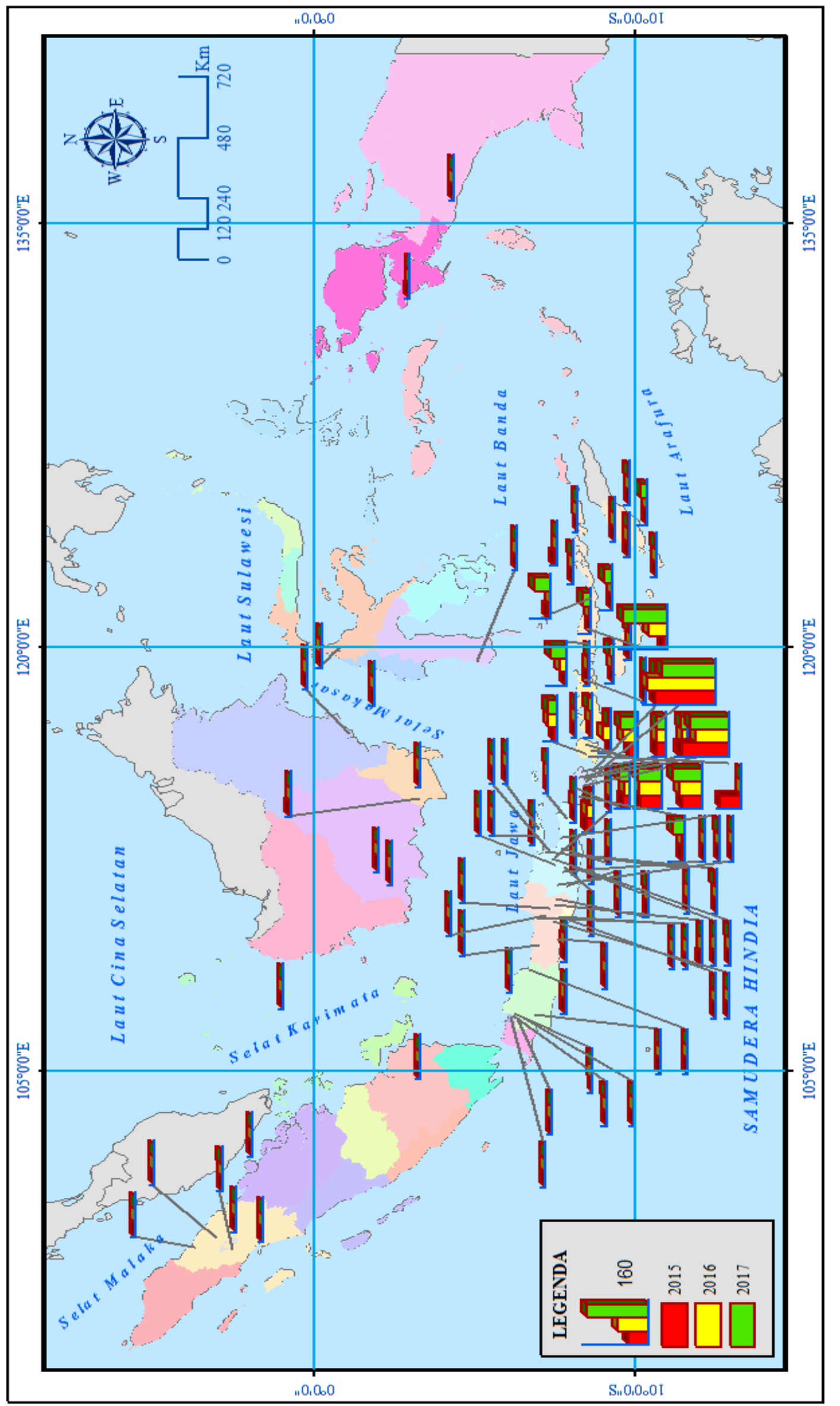

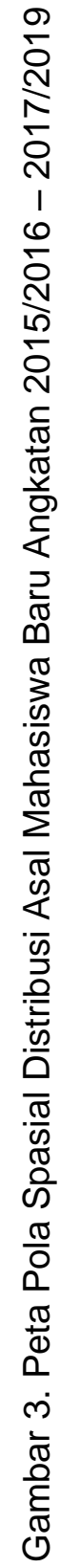

5 | Media Komunikasi Geografi, Vol 20, No. 1, Juni 2019: 1-10 
Dari Grafik dan Peta pola distribusi mahasiswa baru STMIK STIKOM Indonesia menunjukan bahwa asal mahasiswa teraglomerasi pada beberapa wilayah yaitu Bali, Jawa, NTT, dan NTB. Akan tetapi selain Provinsi Bali, dari grafik perbandingan jumlah mahasiswa baru menunjukan bahwa ada tiga provinsi di luar Provinsi Bali yang juga mendominasi dari jumlah mahasiswa baru sepanjang angkatan yaitu, Provinsi Nusa Tenggara Barat, Provinsi Nusa Tenggara Timur dan Provinsi Jawa Timur.
Secara umum jumlah mahasiswa di luar Provinsi Bali tidak sebesar jumlah mahasiswa yang berasal dari Bali sendiri yang mencapi lebih dari $50 \%$ dari total semua mahasiswa. Data perbandingan distribusi mahasiswa STIMIK STIKOM Indonesia pada Provinsi Bali, Provinsi Nusa Tenggara Barat, Provinsi Nusa Tenggara Timur dan Provinsi Jawa Timur dari angkatan 2015/2016-2017/2018 di rinci per kabupaten masing-masing dapat dilihat padat Gambar 4, Gambar 5, Gambar 6, dan Gambar 7.

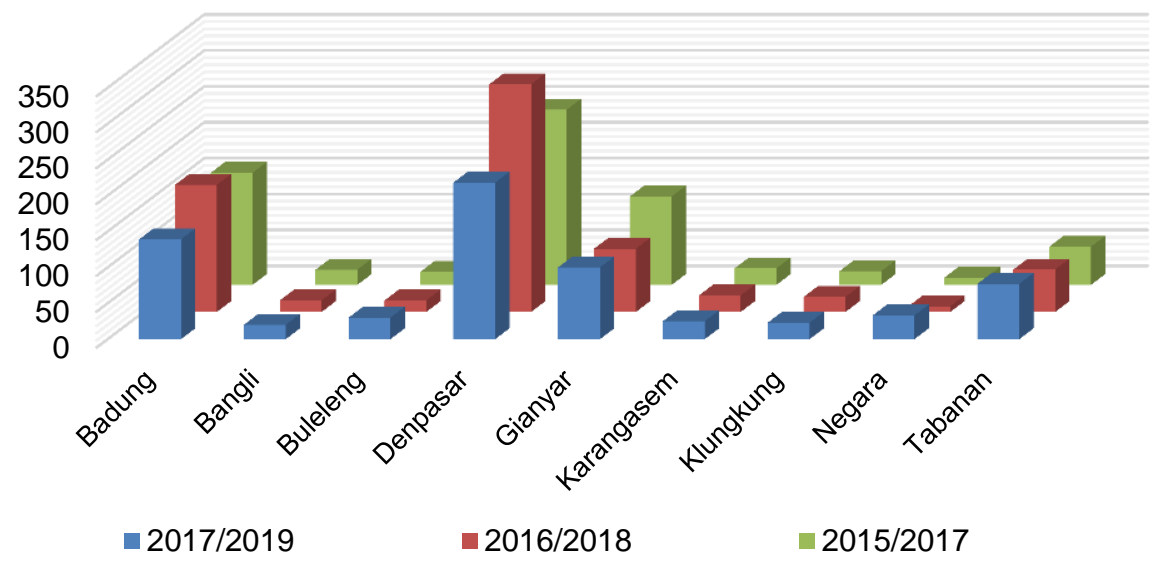

Gambar 4. Perbandingan Jumlah Mahasiwa Baru Provinsi Bali, Pada Angkatan Tahun $2015 / 2016-2017 / 2018$

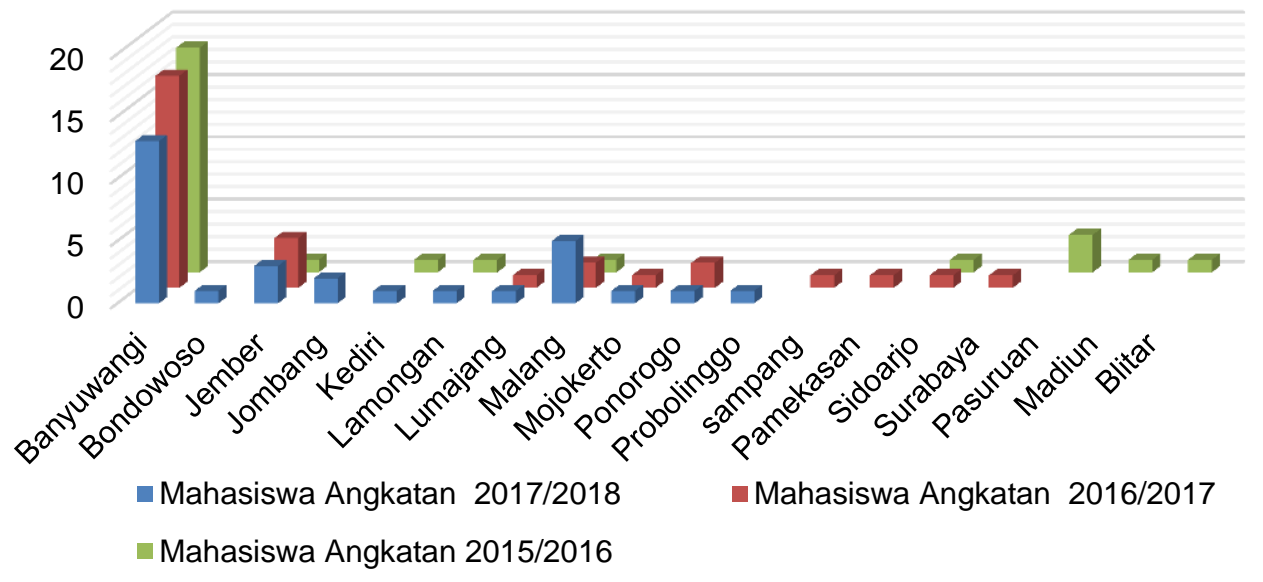

Gambar 5. Perbandingan Jumlah Mahasiwa Baru Provinsi Jawa Timur, Pada Angkatan Tahun 2015/2016 - 2017/2018 


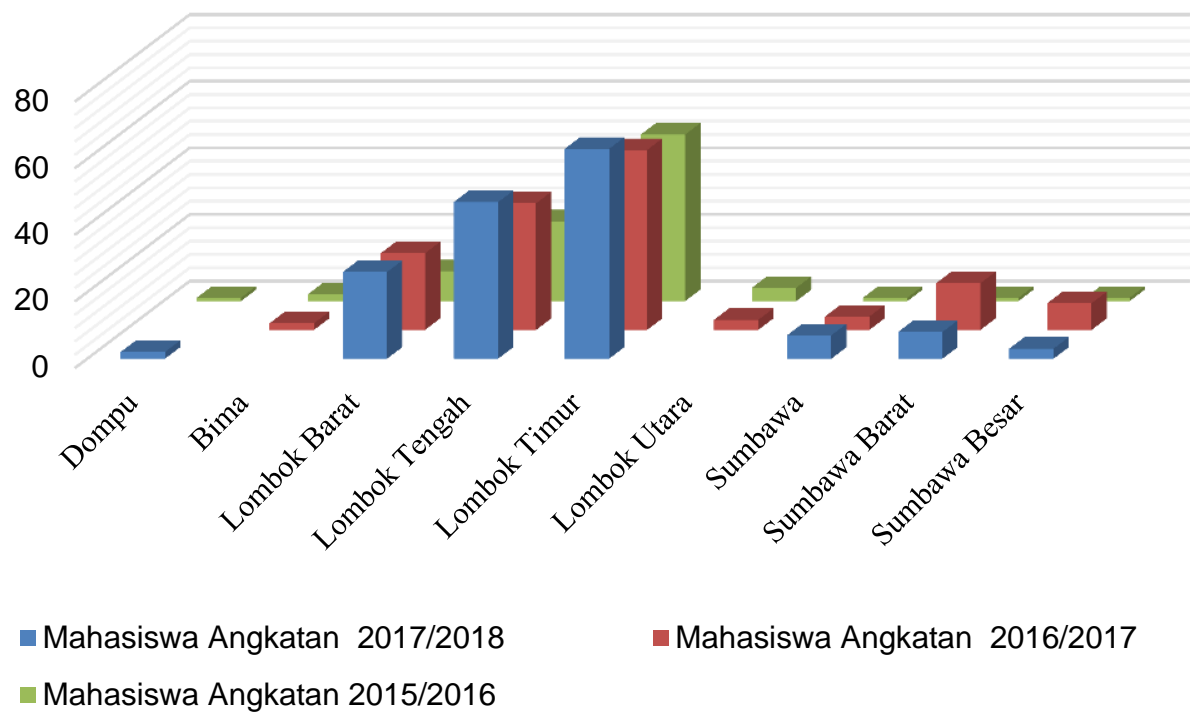

Gambar 6. Perbandingan Jumlah Mahasiwa Baru Provinsi NTB, Pada Angkatan Tahun $2015 / 2016-2017 / 2018$

Gambar 7. Perbandingan Jumlah Mahasiwa Baru Provinsi NTT, Pada Angkatan Tahun $2015 / 2016-2017 / 2018$

\begin{tabular}{|c|c|}
\hline \begin{tabular}{l}
\multicolumn{2}{c}{ Perbandingan data jumlah } \\
mahasiswa pada masing-masing \\
angkatan di Provinsi Bali rata-rata di \\
dominasi oleh wilayah Denpasar, Badung,
\end{tabular} & $\begin{array}{l}\text { merupakan kota dengan penduduk yang } \\
\text { heterogen dan mobilitas penduduk yang } \\
\text { sangat tinggi. Selain itu lokasi } \\
\text { berkembangya }\end{array}$ \\
\hline $\begin{array}{l}\text { Gianyar dan Tabanan (SARBAGITA). Dari } \\
\text { wilayah tersebut Kota Denpasar memiliki } \\
\text { kontribusi yang paling tinggi yatu rata-rata } \\
\text { di atas } 32 \% \text { pada masing-masing } \\
\text { angkatan, ini dikarenakan Kota Denpasar }\end{array}$ & $\begin{array}{l}\text { Indonesia terletak di wilayah pusat } \\
\text { perekonomian dan bisnis kota Denpasar } \\
\text { sehingga selain akses yang sangat dekat } \\
\text { juga menjadi pilihan bagi yang kuliah } \\
\text { sambil bekerja. }\end{array}$ \\
\hline
\end{tabular}


Pada Provinsi Nusa Tenggara Barat terlihat distribusi mahasiswa cukup heterogen pada tahun 2016/2017. Dari pola distribusi tersebut jumlah mahasiswa lebih didominsi oleh Kabupaten Lombok Timur dengan rata-rata $40 \%$, Kabupaten Lombok Tengah dengan rata-rata $26 \%$ dan Kabupaten Lombok Barat rata-rata jumlah mahasiswa sebesar $12 \%$.

Pada provinsi Nusa Tenggara Timur terlihat, dari data jumlah mahasiswa baru tidak menunjukan kecenderungan jumlah penduduk yang sangat mendominasi tetapi lebih mengarh ke tingkat heterogenitas yang cukup tinggi pada masing-masing kabupaten. Ditribusi ini disebabkan karena wilayah NTT yang kepulauan dan banyak tinggal di wilayah pulau-pulau kecil.

Pada Provinsi Jawa Timur jumlah mahasiswa terbanyak berada di Kabupaten Banyuwangi, Banyuwangi secara konsisten dari tahun ketahun menunjukan jumlah mahasiswa terbanyak dibandingkan dengan kabupaten yang lain pada Provinsi Jawa Timur. Dari total mahasiswa asal Provinsi Jawa Timur, jumlah mahasiswa asal Kabupaten bayuwangi rata-rata $50 \%$, walaupun dari tahun ketahun jumlah mahasiswa mengalami penurunan tetapi tetap mendominasi dari semua kabupaten.

\subsection{Tingkat Kepercayaan Publik Pada Lembaga STIMIK STIKOM Indonesia}

Hasil pengolahan data menunjukan adanya peningkatan kepercayaan masyarakat terhadap lembaga perguruan

Dari tiga tahun terakhir menunjukkan bawhwa terjadi peningkatan jumlah mahasiswa yang cukup konsisten dari angkatan tahun 2015/2016 2017/2018. Hasil analisis GIS pada tinggi STMIK STIKOM Indonesia, hal ini ditunjukan dari penigkatan jumlah mahasiswa baru dari tahun ketahun khususnya dari tahun 2015 sampai tahun 2017. Kecendrungan pola distribusi asal mahasiswa mengarah pada aspek "analsisis tetangga terdekat" dan kemudahan mengakses, ini ditunjukan pada gambar 1. bahwa jumlah mahasiswa baru STMIK STIKOM Indoneisa berpusat pada wilayah provinsi bali, NTB, NTT, dan Jawa Timur.

Selain pola distribusi mahasiswa baru, penyajian data spasial mengenai fekuensi dan kecenderungan daya tarik masyarakat dengan lembaga perguruan tinggi STMIK STIKOM Indonesia disajikan dalam sebuah peta yang dapat dilihat pada Gambar 8.

Implementasi sistem informasi geografis, telah mampu memadukan keunggulan data statistik sebagai mesin database atribut dan software SIG sebagai mesin database spatial. Aspek transparansi pada kedua mesin tersebut telah berhasil diimpelementasikan.

Dalam menyajikan data persebaran mahasiswa berdasarkan daerah asal digunakan suatu sistem yang disebut sistem informasi geografis (SIG) yang mengolah data atribut berupa jumlah mahasiswa dari masing-masing daerah dan memasukkannya kedalam peta dasar. Penentuan jumlah mahasiswa berdasarkan jumlah kesluruhan mahasiswa STMIK STIKOM Indonesia Tahun Akademik 2015/2016 sampai dengan 2017/2018 dengan populasi sejumlah 2999.

masing-masing provinsi dan kabupaten menujukan kestabilan dalam grafik jumlah mahasiswa baru khususnya pada provinsi yang dominan dan kabupaten yang dominan dalam wilayah yang sama. 


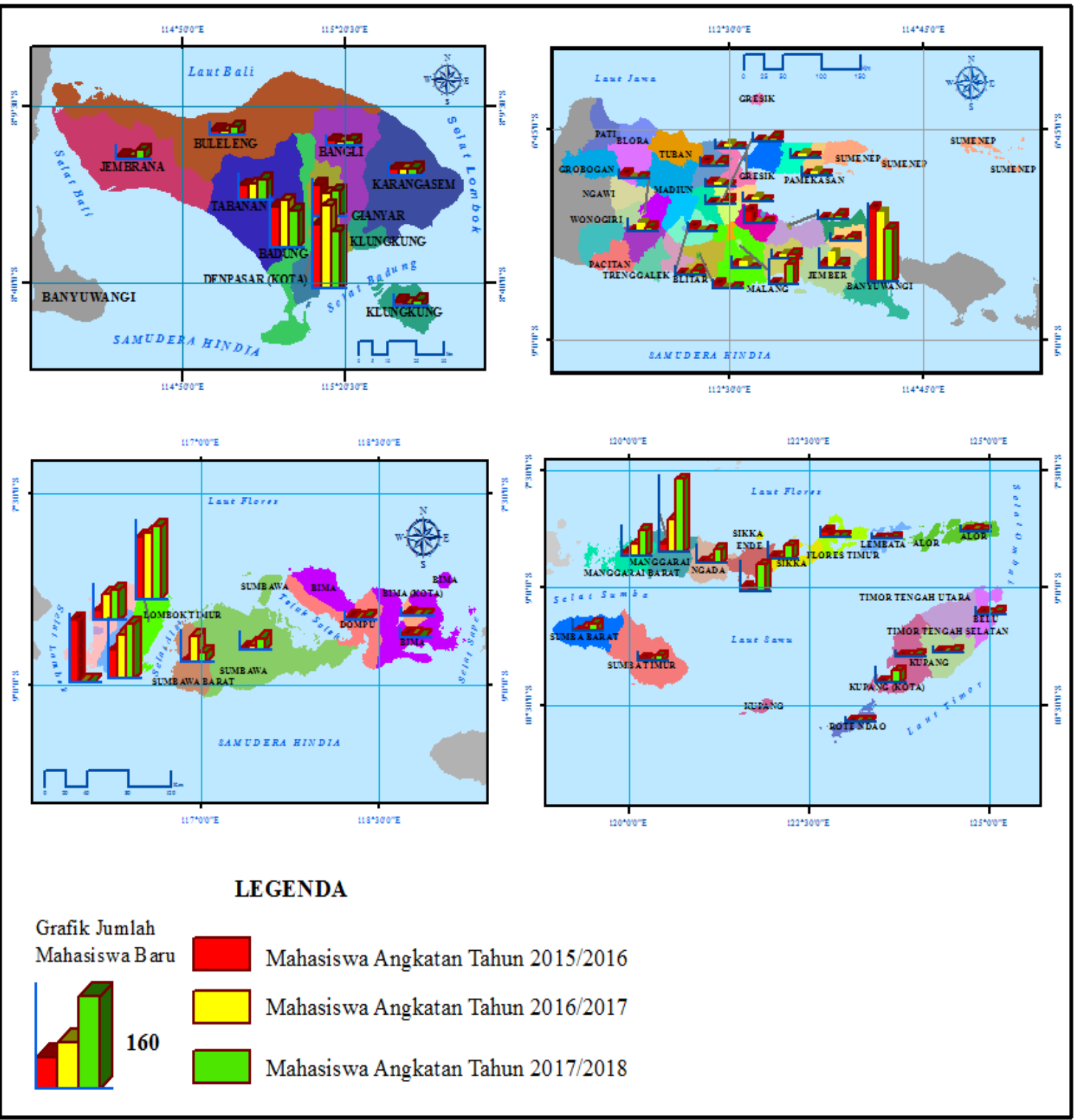

Gambar. 8. Peta Perbandingan Jumlah Mahasiswa Baru dan Kecenderungan Terhadap Kepercayaan Publik.

Dari data tersebut dapat diketahui tingkat kepercayaan masyarakat terhadap STMIK STIKOM Indonesia sebagai lembaga pendidikan yang berbasis teknologi dan informasi sangat tinggi. Tingginya kepercayaan masyarakat dipengaruhi oleh beberapa hal diantaranya, jumlah lembaga perguruan tinggi yang berbasis teknologi dan informasi khususnya wilayah Bali Nusa Tenggara masih berpusat di Provinsi Bali.
Waktu belajar dan kurikulum yang flaksibel menjadi jawaban bagi masyarat yang memiliki tuntutan pekerjaan tetapi memiliki keinginan tinggi untuk meningkatkan pendidikan.

Besarnya derajat konsistensi dan peningkatan jumlah mahasiswa tidak lepas dari pengaruh alumnus yang memberikan kontribusi yang cukup tinggi sebagai media informasi dan promosi secara tidak langsung. Besarnya alumnus 
yang mendapatkan pekerjaan yang layak sebagai indikator dalam tingginya mutu lulusan dari lembaga STMIK STIKOM Indonesia.

\section{Kesimpulan}

Berdasarkan urain tersebut dapat ditarik kesimpulan sebagai berikut. Pertama, terjadi peningkatan jumlah mahasiswa dari 855 mahasiswa pada tahun 2015 manjadi 1129 pada tahun 2018 yang didominasi oleh provinsi Bali, NTT, NTB dan Provinsi Jawa Timur. Kedua, adanya peningkatan kepercayaan masyarakat terhadap lembaga perguruan tinggi STMIK STIKOM Indonesia, dan Kecendrungan pola distribusi asal mahasiswa mengarah pada pemilihan dunia kerja dan kemudahan dalam aksesbilitas.

Adapun saran yang dapat disampaiakan dalam penelitian ini adalah dalam hal pendataan dan sistem registrasi. Dalam pendataan mahasiswa baru perlu dilakukan pendataan yang lebih komprehensif sehingga memiliki mahasiswa yang akuntabel dan kemudahan dalam dalam setiap kebijakan. Di sisi lain, perlu dibuatkan sistem registrasi yang lebih efektif dan memudahkan mahasiswa dalam melaporkan data diri masing-masing sehingga tidak ditemukan mahasiswa yang tanpa identitas.

\section{Daftar Pustaka}

Kompas.com. (2018). Indikator bagi Kualitas Perguruan Tinggi. Tersedia Pada:

https://edukasi.kompas.com/read/201 0/06/26/07261228/Indikator.bagi.Kual itas.Perguruan.Tinggi. Diakses tanggal. 2/06/2018.
Nurkholis. (2013). Pendidikan Dalam Upaya Memajukan Teknologi. Jurnal Kependidikan, 1(1), 24-44.

Rahmanti, A. R., dan Prasetyo, A. K. N. (2012). Sistem Informasi Geografis: Trend Pemanfaatan Teknologi Informasi untuk Bidang Terkait Kesehatan. Proceeding. Seminar Nasional Informatika Medis III.

Ramadhan, T. E., dan Suprayogi, A. (2016). Pemodelan Potensi Bencana Tanah Longsor Menggunakan Analisis Sig Di Kabupaten Semarang. Jurnal Geodesi Undip, 5(1), 1-7.

Riswandi, B. A., dan Hanum, F. F. (2013). Peningkatan Kualitas Siswa Terampil Iptek Dengan Edukasi Komputer Bagi Siswa SD Di Dusun Wonolelo. Jurnal Kependidikan, 2(2), 94-98.

Rohsulina, P., dan Husyain, R. M. (2015). Analisis Persebaran Daerah Asal Mahasiswauniversitas Veteran Bangun Nusantaradengan Menggunakan Sistem Informasi Geografis (SIG). Geoedukasi, 4(2), 10-18.

Siregar, dan Surmalan, J. (2017). Perencanaan Lokasi Sekolah Menengah Pada Subpusat Pelayanan Medan Selayang Berbasis Sistem Informasi Geografis. Universitas Sumatera Utara..

Sukarsa, I. M. (2009). Pemetaan Kualitas Pendidikan di Propinsi Bali Berbasis Spatial. Jurnal Teknologi Elektro, 8(1), 1-6.

Yani, A. (2016). Kebutuhan Basis Data Untuk Aplikasi Sistem Informasi Geografi dalam Era Otonomi Daerah. 